\title{
Pressure Support Ventilation Revisited
}

\author{
Marc H. Lavietes \\ Pulmonary and Critical Care Medicine, University Hospital, Newark, N.J ., USA
}

Pressure support ventilation (PSV) reduces the work of breathing in patients with intrinsic lung disease. When such patients fail and require intubation, PSV facilitates the weaning process, thereby promoting extubation $[1,2]$. By contrast, the role for PSV in the management of patients with respiratory failure but free from intrinsic lung disease is not defined. Many patients would conceivably fit into this category: postoperative patients with normal lung function and patients with neuromuscular diseases, for example.

To this end, Vanpee et al. [3] have presented data in this issue of Respiration describing the effects of PSV when administered to healthy, awake volunteer subjects. Their subjects performed more respiratory work when actively assisting the inspiratory effort delivered by the ventilator (much in the same way a patient would augment the mechanical inhalation during either PSV or proportional assisted ventilation) when compared to work performed during a passive inhalation. By contrast, these subjects performed less work when they resisted the inspiratory effort of the ventilator. These data suggest that resisting mechanical inhalation would confer some benefit for the patient, namely reducing his inspiratory breathing work.

It is difficult to draw a definitive conclusion from this paper regarding the effect of PSV upon breathing work during passive inhalation because control data, that is a measure of breathing work during spontaneous unassisted ventilation, is not given. The reader cannot determine whether or not the work of breathing during an actively assisted inspiration is actually more or less than the work done during spontaneous breathing.

We are also not told to what degree dyspnea is associated with each experimental condition. The fact that relief of dyspnea is not necessarily associated with increasing levels of PSV in patients with lung disease would suggest that the relief of dyspnea is not a requisite for successful weaning during PSV [4]. The ranges of tidal volumes in this study were very great. Subjects breathed 15.8 liters/min during actively assisted breathing but only 6.9 liter/min during the resisted breathing trial. It is inconceivable that either dyspnea or arterial $\mathrm{pCO}_{2}$ would have been the same during all experimental conditions. While reduction of breathing work ought to be accompanied by a reduction of dyspnea, it is also true that $\mathrm{pCO}_{2}$ elevations are associated with worsening of dyspnea in normal subjects. Neither dyspnea scores nor measures of $\mathrm{pCO}_{2}$ are given for these subjects. From the above observations I would conclude that I cannot predict (1) which of these experimental trials would be associated with the greatest reduction of dyspnea and (2) which of these modes would be most favorable for either weaning or maintenance of the patient on long-term ventilation.

Vanpee at al. [3] have presented greatly stimulating preliminary data. We encourage them and others to expand upon this work.

\footnotetext{
References

1 Brochard L, Harf A, Lorino H, Lemaire F: Inspiratory pressure support prevents diaphragmatic fatigue during weaning from mechanical ventilation. Am Rev Respir Dis 1989; 139:513-521.

2 Leung P, Jubran A, Tobin MJ: Comparison of assisted ventilator modes on triggering, patient effort, and dyspnea. Am J Respir Crit Care Med 1997;155:1940-1948.

3 Vanpee D, El Khawand C, Rousseau L, Jamart $\mathrm{J}$, Delaunois L: Influence of respiratory behavior on ventilation, respiratory work and intrinsic PEEP during noninvasive nasal pressure ventilation in normal subjects. Respiration 2002;69:297-302.

4 Knebel AR, Janson-Bjerklie SL, Malley JD, Wilson AG, Marini JJ: Comparison of breathing comfort during weaning with two ventilatory modes. Am J Respir Crit Care Med 1994; 149:14-18.
}

\begin{tabular}{ll}
\hline KARGER & ( ) 2002 S. Karger AG, Basel \\
Fax +41 61306 1234 & $0025-7931 / 02 / 0694-0294 \$ 18.50 / 0$ \\
$\begin{array}{l}\text { E-Mail karger@karger.ch } \\
\text { www.karger.com }\end{array}$ & $\begin{array}{l}\text { Accessible online at: } \\
\text { www.karger.com/journals/res }\end{array}$
\end{tabular}

Marc H. Lavietes, MD

Pulmonary and Critical Care Medicine, University Hospital (I 354)

150 Bergen Street

Newark, NJ 07103-2406 (USA)

Tel. +1973972 6058, Fax +19739726228, E-Mail lavietmh@umdnj.edu 